\title{
Effect of the Rate of Incorporation of Rubber Seed Cake (Hevea brasiliensis) on the Zootechnical Performance of local Ducks (Cairina moschata Linnæus, 1758) in Semi Intensive Breeding in Cote d'Ivoire
}

\author{
Amanidja Boye Donatien ${ }^{1}$ Soro Dofara ${ }^{2}$ and Komara Moussa ${ }^{3}$ \\ ${ }^{1-3}$ UFR Natural Sciences \\ Laboratory of Animal Biology and Cytology \\ Nangui Abrogoua University, Abidjan \\ Côte d'Ivoire
}

\begin{abstract}
A study was conducted on local ducks (Cairina moschata) in the southern forest of Côte d'Ivoire. The aim of the study is to evaluate the growth performance of local ducks fed a rubber seed cake (Hevea brasiliensis) feed in a semi-intensive breeding. In this study, a total of 300 ducklings with an average weight of $50 \pm 5 \mathrm{~g}$ were used. These animals were divided into 2 batches. Each batch contained 150 ducklings. The experimental batch was fed with a feed containing $25 \%$ or $30 \%$ rubber seed cake (TH $25 \%$ or TH 30\%) respectively at startup and in growth. The control batch was fed with a feed without rubber seed cake (TH 0\%). The ducklings were bred for six (06) months. The mean weight gains obtained between the control subjects (males: 555.6 g, females: $467.5 \mathrm{~g}$ ) and the experimental batch (males $656.3 \mathrm{~g}$, females: $579 \mathrm{~g}$ ) were significantly different $(P<0.05)$. The mean average daily gain values were not significantly different ( $P>0.05)$, (males: $66.83 \mathrm{~g}$, females: $61.05 \mathrm{~g}$ ) for the experimental batch and those in the control batch were (males: $59.36 \mathrm{~g}$, females: $53.62 \mathrm{~g}$ ). The Mean consumption index were not significantly different ( $P$ >0.05), (males: 1.8, females: 1.7) for the experimental batch against (males: 2.7, females: 2.1) for the control batch. The incorporation of rubber seed cake into the diet of local ducks seemed to improve the growth performance of these birds.
\end{abstract}

Key Words : Côte d'Ivoire, Local duck, Rubber seed cake, Semi intensive breeding, Zootechnical performances.

\section{INTRODUCTION}

Côte d'Ivoire is highly dependent on international trade in the supply of animal products. Thus, the country imports $60 \%$ of the meat needs of the population [1]. In order to fill the deficit in animal protein, the Ivorian government has oriented his political of developing animal products for the production of short-cycle animals including poultry. Poultry is widely practiced in rural areas, the populations supports about 70\% of the national livestock with approximately 17125000 head in 2001 [2]. Thus, although representing the largest part of the total poultry population. The poultry sector is confronted with several constraints including the high cost of the food which represents $60-80 \%$ of the cost of production. However, to provide solutions to this problem, it is essential to find to develop other food resources known as local unconventional food resources available and that can substitute conventional resources in food formulas. Among these alternative resources are rubber seeds (Hevea brasiliensis) which constitute a source of protein.

The amino acid composition of rubber seeds meal is like soy flour or fish meal excepting methionine, lysine and cystine [3, 4]. Some authors have already used rubber seeds in the diet of layers [5, 6] and pigs in pregnancy and lactation [7]. However, no study to our knowledge has been devoted to its valuation in the diet of the local ducks wherefore the interest of this study.

The present study is designed to evaluate the growth performance of local ducks fed a food made from rubber seed cake in a semiintensive livestock system. 
International Journal of Advances in Scientific Research and Engineering (ijasre), Vol 5 (4), April-2019

\section{MATERIAL AND METHODS}

\subsection{Material}

\subsubsection{Study site}

This experiment was carried out at the Center of Advanced Training and Animal Production. This Center unit is situated in the municipality of Bingerville in the District of Abidjan. From geographic coordinates $5^{\circ} 21^{\prime} 21$ "North and $3^{\circ} 53{ }^{\prime} 24^{\prime \prime}$ West, Bingerville is located in the dense humid tropical forest area where the average annual rainfall was $1653 \mathrm{~mm}$, with an average annual temperature of $26.27 \pm 1.9^{\circ} \mathrm{C}$ and a relative humidity of $81.5 \pm 2.40 \%$.

\subsubsection{Experimental animal}

The study focused on ducklings (Cairina moschata). The total number of animals was 300 ducklings with an average weight of 50 $\pm 5 \mathrm{~g}$.

\subsubsection{Experimental plant}

The experimental plant consisted of rubber seed meal, maize and wheat remolding. These are the ingredients used for the formulation of experimental foods.

\subsubsection{Breeding building}

The building used to conduct this experiment has an area of $150 \mathrm{~m}^{2}, 15 \mathrm{~m}$ long and $10 \mathrm{~m}$ wide. The building has a wall of $40 \mathrm{~cm}$ at the base topped with wire to the roof made of sheet metal. An opening is made at the level of the roof to better allow the circulation of the air. The concrete floor is covered with litter made of wood chips about $10 \mathrm{~cm}$ thick.

\subsubsection{Breeding equipment}

The breeding equipment consisted of 1 st and 2 nd age waterers, 1 st and 2 nd age feeders for watering and feeding. A gas radian was used for heating ducklings during the start-up. An electronic scale for weighing ducks was also used.

\subsubsection{Technical equipment}

The technical equipment consisted of a wooden mallet for crushing seeds, an electric grinder for grinding almonds. An artisanal oil press for the removal of fat, dryers and an electric mixer were used.

\subsection{Methods}

\subsubsection{Collection and treatment of rubber seed}

Rubber seeds (Hevea brasiliensis) were collected in rubber plantations located in the south of Côte d'Ivoire with the agreement of the owners. To facilitate the collection of seeds, some lines have been carefully cleaned. The collected seeds were sun dried on tarps for seven (07) days. The bad seeds were eliminated by manual sorting and the good seeds kept in bags at ordinary temperature $\left(28^{\circ} \mathrm{C}\right)$ for the manufacture of the cake.

\subsubsection{Production of rubber seed cake}

Dried rubber seeds are shelled manually by crushing, seed by seed, using a wooden mallet. The almonds thus obtained pass to the autoclave at $105^{\circ} \mathrm{C}$. during 24 hours. Then, they are cooled by spreading in basins during two (02) hours. After that, the almonds are crushed by a grinding machine. The ground matter obtained is mixed homogeneously with water at the rate of two (02) liters per $10 \mathrm{~kg}$ of crushed fines. The homogenate obtained is subjected to a manual oil press until maximum elimination of the fat. The fat removed, the block of cake collected is crushed, then dried for three (03) days in the sun and stored in dry bags.

\subsubsection{Formulation of experimental rations}

Two types of experimental foods were formulated from the results of the analysis of rubber seed cake (Table 1). These are, the starter food ( $\mathrm{TH} \mathrm{25 \% )}$ ) and the growth food (TH 30\%). They were formulated based on rubber seed cake incorporated at $25 \%$ for startup and $30 \%$ for growth. The formulation was made in order to substitute the maximum amount of fish meal while respecting the protein content required for ducks. In addition to the cake, other raw materials have been used such as maize and wheat remolding. These rations were formulated at the zootechny service of poultry department of the center. The control food (TH $0 \%$ ) was an industrial feed purchased in the commerce and containing not rubber seed cake. 
International Journal of Advances in Scientific Research and Engineering (ijasre), Vol 5 (4), April-2019

Table 1 : Percentage composition, nutritional and energy value of food rations TH $0 \%$, TH $25 \%$ and TH $30 \%$ tested in ducklings.

\begin{tabular}{|c|c|c|c|c|}
\hline \multirow{3}{*}{ Ingredients } & \multicolumn{4}{|c|}{ Food rations } \\
\hline & \multicolumn{2}{|c|}{${ }^{1}$ TH $0 \%$} & \multirow{2}{*}{$\frac{{ }^{2} \text { TH } 25 \%}{\text { Start-up }}$} & \multirow{2}{*}{$\begin{array}{c}{ }^{3} \text { TH } 30 \% \\
\text { Growth }\end{array}$} \\
\hline & Start-up & Growth & & \\
\hline Maize (\%) & 58.00 & 63.50 & 43.68 & 50.00 \\
\hline Wheat remolding (\%) & 19.15 & 22.80 & 20.00 & 12.27 \\
\hline Fishmeal (\%) & 19.00 & 10.40 & 7.50 & 4.00 \\
\hline Rubber cake (\%) & 0.00 & 0.00 & 25.00 & 30.00 \\
\hline Shellfish (\%) & 0.50 & 0.50 & 0.70 & 0.43 \\
\hline Bicalcic phosphate (\%) & 0.90 & 0.70 & 0.62 & 1.50 \\
\hline CMV & 0.75 & 0.25 & 0.89 & 0.10 \\
\hline Lysine (\%) & 0.90 & 1.00 & 0.90 & 0.90 \\
\hline Methionine (\%) & 0.50 & 0.60 & 0.41 & 0.50 \\
\hline Cooking salt (\%) & 0.30 & 0.25 & 0.30 & 0.50 \\
\hline Total & 100 & 100 & 100 & 100 \\
\hline Dry matter (\%) & 89.73 & 89.06 & 90.20 & 89.13 \\
\hline Protein (\%) & 19.01 & 16.00 & 19.00 & 16.00 \\
\hline $\begin{array}{c}\text { Metabolizable energy } \\
\text { (kcal/kg) }\end{array}$ & 3007 & 2802 & 3009 & 2800 \\
\hline Calcium (\%) & 1.43 & 1.11 & 0.84 & 0.75 \\
\hline Phosphorus (\%) & 0.89 & 0.63 & 0.45 & 0.35 \\
\hline
\end{tabular}

\subsubsection{Acquisition of local ducklings}

The local ducklings were obtained after an artificial incubation of the eggs collected from the breeders chosen for this study. The collected eggs were carefully stored in cells and transported to the Laboratory of Animal Biology and Cytology for storage. After three (03) days of storage, the eggs were sent to the hatchery.

\subsubsection{Breeding of local ducks}

The experiment was conducted to six (06) months divided into two (02) phases. The start-up phase lasted 1 month and the growth phase 5 months. During the start-up phase, the subjects were divided into two (02) batches, one experimental and the other control. Each batch contained 150 local ducklings. During this phase, the animals were warmed using radian placed inside the breeding buildings. Subjects in the experimental batch were fed with TH 25\% diet and TH 0\% diet for the controls at start-up. After a month of breeding when sexual dimorphism was established the males were separated from the females in each batch. A total of 38 males and 37 experimental females compared to 37 females and 38 control males were separated. During the growth phase, males and females were fed distinctly. Experimental males and females were fed with TH $30 \%$ diet. As for the controls, they were fed with TH $0 \%$ growth food containing no rubber seed cake. Food was served in the birdfeeders twice daily (morning and evening). The drinking water was distributed in ad libitum. An established medical prophylaxis program has permitted to vaccinate the ducklings against Newcastle diseases, Gumboro and make the different reminder. Deworming was every three weeks using Piperazine Citrate or Albendazole.

\subsubsection{Zootechnical measures}

Food refusals were weighed regularly before each new distribution. Animals were weighed every week in each batch early in the morning. The dead subjects have been collected. All these data have been recorded in breeding datasheets. All these operations are permitted to determine the food intake, the weight gain, the average daily gain, the feed consumption and the mortality rate.

\subsubsection{Data analysis}

The statistical analysis of the results was carried out according two-factor model (effect of the incorporation of the rubber seed cake or the sex on the growth parameters). These factors were analyzed by the software R version 3.0.3 using an ANOVA test. The mortality rate was compared by a chi-square test. 


\section{RESULTS AND DISCUSSION}

\subsection{Results}

3.1.1 Effects of rubber seed cake on food intake of local ducks

Table 2 presents the food intake of local ducks by type of food distributed, sex and breeding periods. During the experiment, food intake was increasing in the both batch, as well as to the males and the females. The average ingestion values obtained at the control batches are all higher than the experimental batches with significant differences $(\mathrm{P}<0.05)$.

Table 2 : Variation of food intake of local ducks by type of distributed food, sex and breeding periods.

\begin{tabular}{|c|c|c|c|c|c|c|c|c|}
\hline & & \multicolumn{3}{|c|}{ Breeding periods } & Distributed fo & & & \\
\hline Start up & \multirow{2}{*}{ Male/Female } & ${ }^{1} \mathrm{TH} \mathrm{0 \%}$ & ${ }^{2} \mathrm{TH} 25 \%$ & $E S$ & \multicolumn{4}{|c|}{$\boldsymbol{P}$} \\
\hline Month 1 & & 930.5 & 685.3 & 13.70 & \multicolumn{4}{|c|}{0.004} \\
\hline Growth & ${ }^{1} \mathrm{TH} \mathrm{0 \%}$ & ${ }^{3} \mathrm{TH} \mathrm{30 \%}$ & $E S$ & $P$ & ${ }^{I} \mathrm{TH} \mathrm{0 \%}$ & ${ }^{3} \mathrm{TH} \mathrm{30 \%}$ & $E S$ & $P$ \\
\hline Month 2 & 1023 & 769.45 & 15.50 & 0.001 & 732 & 720 & 08.60 & 0.004 \\
\hline Month 3 & 1225.55 & 1030.4 & 09.57 & 0.002 & 943.8 & 913 & 16.09 & 0.003 \\
\hline Month 5 & 1988.82 & 1531.25 & 08.25 & 0.007 & 1345.6 & 1311 & 09.70 & 0.003 \\
\hline Month 6 & 2558.4 & 2104.56 & 14.80 & 0.004 & 1512.5 & 1488.08 & 10.20 & 0.002 \\
\hline Mean & $1578.21^{a} \pm 92$ & $1248.24^{b} \pm 86$ & 224.6 & 0.009 & $1106.9^{a} \pm 80$ & $1034.9^{b} \pm 72$ & 227.9 & 0.002 \\
\hline
\end{tabular}

${ }^{1} \mathrm{TH} 0 \%$ : Feed without rubber seed cake

${ }^{2} \mathrm{TH} 25 \%$ : Feed containing $25 \%$ rubber seed cake

${ }^{3} \mathrm{TH} 30 \%$ : Feed containing 30\% rubber seed cake

ES : Standard Error, P : Probability

Mean values with different letters on the same line are significantly different $(p<0.05)$.

\subsubsection{Effect of rubber seed cake on weight gain of local ducks}

Table 3 presente the weight gains of local ducks by type of food distributed, sex and breeding periods. The weight gains of the ducklings varied according to the rearing phase. During the start-up phase, no significant difference $(\mathrm{P}>0.05)$ was observed between the ducklings fed with TH $25 \%$ and the ducklings fed with TH $0 \%$ ration. During the growth phase, as well as to the males and the females, weight gains increased gradually until the end of the trial. Significant differences $(\mathrm{P}<0.05)$ between the control and experimental batch were observed at month 2, month 4, month 5 and month 6 respectively to the males and the females. At this period, weight gain rates of $80.03 \%$ in experimental males and $78.14 \%$ in control males were recorded. In females, significant differences $(\mathrm{P}<0.05)$ were noted at month 5 and month 6 with weight gain rates of $77.27 \%$ for the control batch and $81.32 \%$ for the experimental batch.

Table 3 : Variation in weight gain of local ducks by type of distributed food, sex and breeding periods.

\begin{tabular}{|c|c|c|c|c|c|c|c|c|}
\hline \multirow[b]{2}{*}{ Start-up } & \multicolumn{3}{|c|}{ Breeding periods } & \multicolumn{3}{|c|}{ Distributed food } & & \\
\hline & \multicolumn{2}{|c|}{ Male /Female } & ${ }^{1} \mathrm{TH} \mathrm{0 \%}$ & \multicolumn{2}{|c|}{${ }^{2} \mathrm{TH} 25 \%$} & $E S$ & \multicolumn{2}{|c|}{$P$} \\
\hline Jo & & & 50 & \multicolumn{2}{|c|}{50} & - & \multicolumn{2}{|c|}{-} \\
\hline Month 1 & & & 385 & \multicolumn{2}{|c|}{450} & 130.68 & \multicolumn{2}{|c|}{0.63} \\
\hline Sex & \multicolumn{2}{|c|}{ Male } & & \multicolumn{3}{|c|}{ Female } & & \\
\hline Growth & ${ }^{1} \mathrm{THO} \%$ & ${ }^{3} \mathrm{TH} 30 \%$ & $E S$ & $P$ & ${ }^{1} \mathrm{THO} \%$ & ${ }^{3} \mathrm{TH} 30 \%$ & $E S$ & $P$ \\
\hline Month 2 & 458 & 550 & 39.63 & 0.002 & 400 & 480 & 73.60 & 0.560 \\
\hline Month 3 & 560 & 635 & 74.14 & 0.185 & 492 & 550 & 80.02 & 0.153 \\
\hline Month 4 & 595 & 700 & 92.80 & 0.007 & 535 & 600 & 96.70 & 0.186 \\
\hline Month 5 & 625 & 783 & 72.42 & 0.002 & 580 & 690 & 60.27 & 0.004 \\
\hline Month 6 & 711 & 820 & 73.60 & 0.001 & 605 & 712 & 87.69 & 0.006 \\
\hline Mean & $555.6^{a} \pm 8.92$ & $656.3^{b} \pm 91.6$ & 224.6 & 0.009 & $467.5^{a} \pm 88.88$ & $579^{b} \pm 80.0$ & 227.9 & 0.002 \\
\hline
\end{tabular}

${ }^{1} \mathrm{TH} 0 \%$ : Feed without rubber seed cake

${ }^{2} \mathrm{TH} 25 \%$ : Feed containing $25 \%$ rubber seed cake

${ }^{3} \mathrm{TH} 30 \%$ : Feed containing $30 \%$ rubber seed cake

J0 : live weight at a day of age

ES : Standard Error, P : Probability

Mean values with different letters on the same line are significantly different $(\mathrm{p}<0.05)$. 


\subsubsection{Effect of rubber seed cake on the average daily gain of local ducks}

The average daily gains of local ducks obtained by type of food distributed, sex and breeding periods are reported in Tables 4 . In both males and females, the average daily gain varied in the both (02) batches. Thus, in experimental males of $15 \mathrm{~g}$ in the start-up phase, the animals reached an average daily gain of $27.33 \mathrm{~g}$ at the end of the growth period. In the males of the control batch of $12.83 \mathrm{~g}$ at the beginning of breeding, the subjects switched to an average daily gains of $23.7 \mathrm{~g}$. However, there is no significant difference $(P>0.05)$ between the control and experimental batch. In females, the average daily gains during growth ranges from $13.33 \mathrm{~g}$ to $21.16 \mathrm{~g}$ for the control batch and from $16 \mathrm{~g}$ to $23.76 \mathrm{~g}$ for the experimental batch. No significant difference $(\mathrm{P}>0.05)$ between the mean average daily gain of the control batch and the experimental batch was observed.

Table 4 : Variation in the average daily gain of local ducks according to the type of distributed food, the sex and the breeding periods.

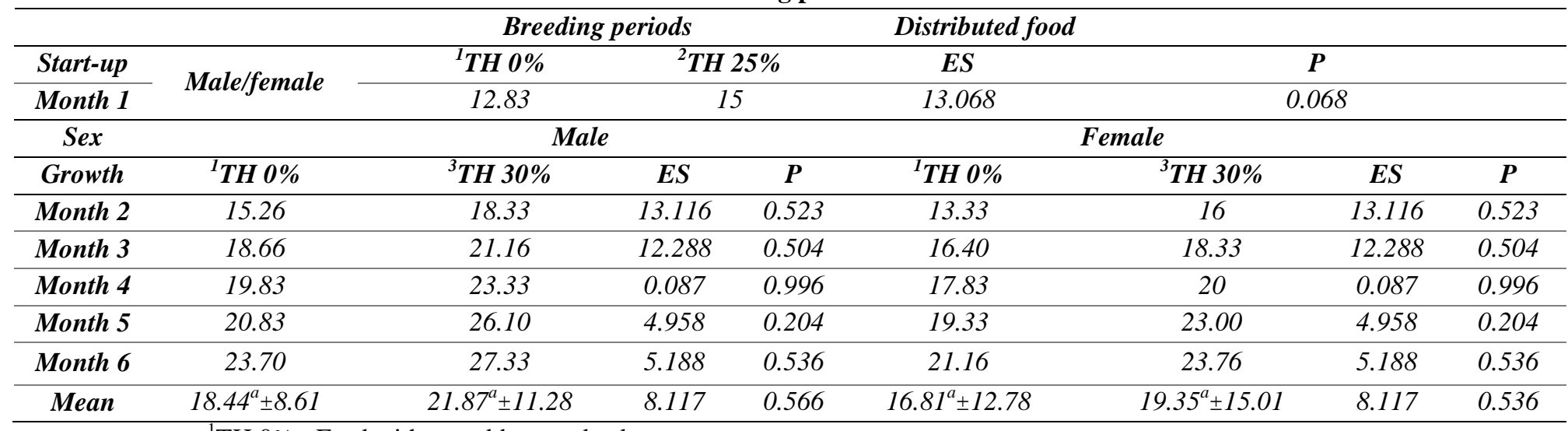

${ }^{\mathrm{I}} \mathrm{TH} 0 \%$ : Feed without rubber seed cake

${ }^{2} \mathrm{TH} 25 \%$ : Feed containing $25 \%$ rubber seed cake

${ }^{3}$ TH $30 \%$ : Feed containing 30\% rubber seed cake

ES : Standard Error, P : Probability

Mean values with different letters on the same line are significantly different $(\mathrm{p}<0.05)$.

3.1.4 Effect of rubber seed cake on the consumption index of local ducks

The consumption index of local ducks recorded by type of food distributed, sex and breeding periods during the trial are shown in Table 5. The results show that rubber did not have any significant adverse effects on the duck consumption index but rather improved it. The lowest consumption indices were recorded in the experimental subjects. However, no significant difference (P > 0.05 ) between the consumption index of the experimental batch and control batch was observed.

Table 5 : Variation in the consumption index of local ducks according to the type of distributed food, sex and breeding periods.

\begin{tabular}{|c|c|c|c|c|c|c|c|c|}
\hline & \multirow{3}{*}{ Male/Femelle } & \multicolumn{3}{|c|}{ Breeding periods } & \multicolumn{3}{|c|}{ istributed food } & \\
\hline \multirow{2}{*}{\begin{tabular}{|l|} 
Start-up \\
Month 1 \\
\end{tabular}} & & ${ }^{{ }^{I} \text { TH 0\% }}$ & ${ }^{2} \mathrm{TH} 25^{\circ}$ & & $E S$ & & $P$ & \\
\hline & & 2.4 & 1.4 & & 0.24 & & 0.994 & \\
\hline Sex & & ale & & & & & & \\
\hline Growth & ${ }^{1}$ TH 0\% & ${ }^{3} \mathrm{TH} \mathrm{30 \%}$ & $E S$ & $P$ & ${ }^{I} \mathrm{TH} 0 \%$ & ${ }^{3} \mathrm{TH} \mathrm{30 \%}$ & $E S$ & $P$ \\
\hline Month 2 & 2.2 & 1.4 & 0.382 & 0.900 & 1.8 & 1.5 & 0.225 & 0.154 \\
\hline Month 3 & 2.1 & 1.6 & 0.238 & 0.992 & 1.9 & 1.6 & 0.114 & 0.183 \\
\hline Month 4 & 2.9 & 1.9 & 0.087 & 0.996 & 2.2 & 1.8 & 0.202 & 0.008 \\
\hline Month 5 & 3.1 & 1.9 & 0.003 & 0.757 & 2.3 & 1.9 & 0.470 & 0.123 \\
\hline Month 6 & 3.5 & 2.5 & 0.038 & 0.994 & 2.5 & 2.0 & 0.054 & 0.188 \\
\hline Mean & $2.7^{a} \pm 0.6$ & $1.8^{a} \pm 0.6$ & 0.267 & 0.938 & $2.1^{a} \pm 0.4$ & $1.7^{a} \pm 0.5$ & 0.223 & 0.275 \\
\hline
\end{tabular}

${ }^{\mathrm{I}} \mathrm{TH} 0 \%$ : Feed without rubber seed cake

${ }^{2} \mathrm{TH} 25 \%$ : Feed containing $25 \%$ rubber seed cake

${ }^{3}$ TH $30 \%$ : Feed containing 30\% rubber seed cake

ES : Standard Error, P : Probability

Mean values with different letters on the same line are significantly different $(p<0.05)$. 


\subsubsection{Mortality rate of local ducks}

Table 6 presents the mortality rate of local ducks by type of food distributed, sex and breeding periods. During the trial, ducks fed with TH $0 \%$ diet had higher mortality rates than ducks fed with $\mathrm{TH} 25 \%$ and $\mathrm{TH} 30 \%$ diets. However, no significant difference (P>0.05) was observed.

Table 6 : Mortality rates of local ducks by type of distributed food, sex and breeding periods

\begin{tabular}{|c|c|c|c|c|}
\hline \multirow{2}{*}{$\begin{array}{c}\text { Breeding periods } \\
\text { Distributed food }\end{array}$} & \multicolumn{2}{|l|}{ Start-up } & \multicolumn{2}{|c|}{ Growth } \\
\hline & ${ }^{1} \mathrm{TH} \mathrm{0 \%}$ & ${ }^{2} \mathrm{TH} 25 \%$ & ${ }^{1} \mathrm{TH} \mathrm{0 \%}$ & ${ }^{3} \mathrm{TH} \mathrm{30 \%}$ \\
\hline Starting effective & 150 & 150 & 143 & 145 \\
\hline Nombre d'animaux morts & 7 & 5 & 3 & 1 \\
\hline Effective at the end of period & 143 & 145 & 140 & 144 \\
\hline Death rate $(\%)$ & $4.6^{a}$ & $3.3^{a}$ & $2^{a}$ & $0.6^{a}$ \\
\hline Total death rate per distributed food (\%) & \multicolumn{2}{|c|}{ THO $\%$} & \multicolumn{2}{|c|}{ TH $25 \%-30 \%$} \\
\hline
\end{tabular}

${ }^{1} \mathrm{TH} 0 \%$ : Feed without rubber seed cake

${ }^{2}$ TH $25 \%$ : Feed containing $25 \%$ rubber seed cake

${ }^{3} \mathrm{TH} 30 \%$ : Feed containing $30 \%$ rubber seed cake

Mean values with different letters on the same line are significantly different $(\mathrm{p}<0.05)$.

\section{DISCUSSION}

In our trial, experimental local ducks had a low average food intake (male :1248.24 g and female :1034.9g) compared to control batches (male :1578.21 g and female: $1106.9 \mathrm{~g}$ ) in starting and the growth. This reduction in food intake could be justified by the fact that they found in the food that was distributed them, the necessary nutrients to cover their needs. Thus the food made with rubber seed cake seems to have covered the nutritional needs and ensured the energy equilibrium of the ducks.

In our study, there was no significant difference during the start-up phase of our experiment regarding weight gain. However, significant differences were observed during the growth phase, at the second, fourth, fifth and sixth months. In fact, the males and females of the experimental batches had greater weight gains (male : $656.3 \mathrm{~g}$ and female: $579 \mathrm{~g}$ ) than the males and females of the control batches (male: $555.6 \mathrm{~g}$ and female: $465.5 \mathrm{~g}$ ). Overall, the weight gains obtained during this study are similar to those reported by $[8,9]$ in Muscovy ducks in three breeding.

However, the weight gains obtained in our study are completely higher than those recorded in Muscovy ducks in Nigeria [10, 11, 12]. These authors in their studies recorded weight gains ranging between $466.67 \mathrm{~g}$ and $507.07 \mathrm{~g}$ for males, and between $257.67 \mathrm{~g}$ and $373.83 \mathrm{~g}$ for females. This difference could be related to the food because we incorporated rubber seed cake while they incorporated blocks of concentrate in the feed of Muscovy ducks. In addition, our study confirmed the variability associated with sexual dimorphism in ducks. In fact, the weight gains of the males were greater than those of the females during the growth phase. The average daily gains in our study was not different between the control (male : $18.44 \mathrm{~g}$ and female :16.81 g) and experimental batches (male :21.87 g and female : $19.35 \mathrm{~g}$ ) during the start-up and growth phases. Our average daily gains results (12.83 to $21.87 \mathrm{~g}$ ) are similar to those obtained in other muscovy ducks (15.87 to $16.07 \mathrm{~g}$ ) in Nigeria by [12]. However, the average daily gains of our results are generally lower than those reported by [13] in hybrid breeds of duck under automatic concentrate dispenser. This difference could be due to crossbreeding and / or food or feeding.

The consumption index in our study was not different between the control and experimental batches during the start-up and growth phases. The consumption index of local ducks in our growing control batches (2.7 for males and 2.1 for females) is near for the males reported of 2.8 for Mulard ducks [9].

Concerning mortality rates of local ducks in our experiment, no difference was noted between control and experimental batches. Moreover, the mortality rates recorded in our study are located in the interval of the standards (3 to 5\%) authorized in modern poultry breeding in tropical areas [14]. Which suggests that our incorporation rates of rubber seed cake are satisfactory, as they have not increased the mortality rate of local ducks.

\section{CONCLUSION}

At the end of our study, it appears that the incorporation of rubber seed cake into the diet of local ducks in semi-intensive breeding has improved their weight gain and reduced their food consumption. In addition, there was no negative effect of this incorporation on their average daily gain, consumption index and mortality rate for local ducks. In view of these results, and because of the high 
cost of other raw materials as sources of protein in rural areas, the valorization of the detoxified meal of rubber seeds in the diet of the local ducks in growth is to be encouraged in the regions where they are available.

\section{CONFLICT OF INTEREST}

With regards to this research, the authors declare that they have no conflicting interest.

\section{REFERENCES}

1. MIRAH (Ministère des Ressources Animales et Halieutiques). 2009. Note d'orientation de l'atelier de planification stratégique du Plan Stratégique de Relance de l'Aviculture Ivoirienne (PASRA) Abidjan- Cote d'Ivoire Novembre 2009, p8.

2. MIRAH (Ministère des Ressources Animales et Halieutiques). 2005. Production, Importation et Consommation de la viande de 1990 à 2004. Direction de la planification et des programmes, données statistiques, Cote d'Ivoire, p27.

3. Kumar A, and Samph R.1979. Chemical composition and nutritive value of rubber seed cake. Indian Journal of Dairy Sciences, 32 (1) : 58-61.

4. Udo D, Ekpo U, and Ahamefule O. 2016. Effects of processing on the nutrient composition of rubber seed meal. Journal of the Saudi Society of Agricultural Sciences, 92 : 4287-4295

5. Buvanendran V, and Sirwardene A. 1970. Rubber seed meal in poultry diets. Ceylon Veterinary journal, 18 (2) : $33-36$.

6. Ocho A, Atcho O, Kouakou B, and Keli J. 2008. La graine d'hévéa appauvrie en acide cyanhydrique par la méthode de triple séchage offre un tourteau propre à la consommation de la poule pondeuse. Revue Africaine de Santé et de Productions Animales, E.I.S.M.V. de Dakar, 6 : 3-4.

7. Koné G, Monique E, Bertin K, De Paul F, and Maryline K. 2016. Étude préliminaire de la valorisation des tourteaux d'hévéa, d'anacarde et de pourghère chez les porcs durant la gestation et la lactation, European Scientific Journal,12 (30) : 13-20.

8. Baéza E, Rideau N, and Chartrin P. 2005. Effects of presentation and type of cereals (maize or sorghum) on performance of geese.Canards de Barbarie, Pékin et leurs hybrides. Poultry Science Journal, 91 : 2063-2071.

9. Guerin JL. 2008. L’élevage des canards de barbarie. France Agricole, p15.

10. Meulen V, and Dikken D.1999. L'élevage des canards CTA. Agrodok Serie, 33 : 23-59.

11. Ola I. 2000. Vital reproductive and productive characteristics of the Nigerian Muscovy duck. Proceedings of 25th Annual NSAP Conference, pp.188-190.

12. Etuk F, and Abasiekong F. 2006. Duck production in average of 1821 grammes of growth and feed utilization, South Eastern (Nigeria), Journal of Agriculture Food, 2 : 456-457.

13. Cobo E, Gilbert H, Lagüe M, Laverze J, Ricard E, Cornuez A, Martin X, Drouilhet L, and Marie-Etancelin C. 2015. Comparaison du comportement alimentaire de canards de barbarie et mulards. Onzièmes Journées de la Recherche Avicole et Palmipèdes à Foie Gras, Tours, les 25 et 26 mars 2015, p7.

14. Dayon J, and Arbelot B. 1997. Guide d'élevage des volailles au Sénégal, Dakar ISRA LNERV, p101. 